УДК: 811.161.2(477)

Л. Б. Шутак

\title{
ДО ПИТАННЯ МОВНОЇ ПОЛІТИКИ В УКРАЇНІ
}

Шутак Л. Б. До питання мовної політики в Україні.

Одним із основних виявів самоутвердження нації є державний статус іiі мови, функціонування державної мови в усіх сферах суспільного життя. Для цього слід впроваджувати державну мовну політику відповідно до конституційних норм та міжнародно-правових зобов'язань України. Дослідження $\epsilon$ фрагментом наукової теми «Вивчення цінностей у системі науки та культури», виконуваної кафедрою суспільних наук та українознавства Буковинського державного медичного університету.

Ключові слова: державна (офіційна) мова, європейські мови, мовна політика, україномовне середовище, функціонування державної мови.

Шутак Л. Б. К вопросу о языковой политике в Украине.

Одним из основных проявлений самоутверждения нации есть государственный статус ее языка, функционирование государственного языка во всех сферах жизни. Для этого необходимо внедрять государственную языковую политику, которая должна отвечать конституционным нормам и международно-правовым обязательствам Украины.

Ключевые слова: государственный (официальный) язык, европейские языки, языковая политика, украиноязычная среда, функционирование государственного языка.

Shutak L. B. To the question of language policy in Ukraine.

State status of its native language and functioning of a state language in all the spheres of social life is supposed to be one of the basic manifestations of a nation self-assertion and consolidation. To achieve this aim it is obligatory to introduce state language policy according to Constitutional norms and international law obligations of Ukraine. The present investigation is a fragment of a scientific theme: «Study of values in the system of science and culture», being carried out by the department of social sciences and Ukrainology of Bukovinian state medical university.

Key words: state (official) language, European language, language policy, Ukrainian (language) environment, state language functioning.

Українська мова - одна 3 найдавніших мов, що постала 3 праслов'янської. Деякі вчені пов'язують іiі виникнення 3 часом, коли з'являються слов'янські племена і зароджуються слов'янські мови, інші доводять спорідненість української мови 3 латиною, грецькою та санскритом, починаючи їі відлік від VI-VII ст. до н. е. Усі версії зводяться до того, що українська мова - багата, милозвучна, високорозвинена 
європейська мова. Вона не поступається своїми функціональними можливостями жодній із найбагатших і найрозвиненіших мов світу.

Одним із найважливіших виявів самоутвердження нації є державний статус їі мови, що законодавчо забезпечує іï функціонування в усіх сферах суспільного життя. Проблема статусу української мови, іiі місця в житті країни, соціокультурному контексті висвітлювалася відомими українськими мовознавцями Л. Масенко, М. Жулинським, I. Дзюбою, А. Погрібним, С. Срмоленко, О. Ткаченком, М. Вівчариком, вченимиісториками Я. Калакурою, В. Василенком та ін., західноєвропейськими дослідниками, проте залишається актуальною й досі. Отже, вибір теми статті значною мірою випливає 3 проблем сьогодення, хоч до питання взаємозв’язку «мова і держава», «статус мови в державі», однієї з найбільш фундаментальних і вічних, неодноразово зверталися і видатні мислителі, i суспільно-громадські діячі, і провідні мовознавці України і світу.

Згадаємо Анаксагора, мова якого є взірцем філософської й літературної творчості. Сократ дав ідеальне розв’язання проблеми «мова філософії» і «філософія мови». Державний ідеолог Платон трактував роль мови як універсальної форми («Держава», «Закони»). Аристотель був поборником єдності політики, етики і мови. Центральною проблемою виховання, навчання та державного будівництва була мова для Я.Коменського. Особливо яскраво мовні контексти державної політики викладені у творчості Ф. Бекона, лінгвістичні проблеми буття притаманні філософії Т. Гоббса та Дж. Локка, класикою мовно-філософської системи мислення є література Вольтера.

В Україні мовне питання було актуальним, починаючи 3 часів розпаду Київської Русі. Усі українські вчені, філософи і мовознавці ототожнювали поняття «мова» й «держава» i розуміли, що розвиток української держави нерозривно пов'язаний з розвитком української мови (Г. Сковорода, Т. Шевченко І. Франко, Леся Україна тощо). Незважаючи на численні офіційні заборони, українська мова жила у творчості видатних українських патріотів-письменників, учених, публіцистів. Ідеологами та теоретиками української національної ідеї, а отже, і визнання державності українською мовою, виступили М. Грушевський та I. Огієнко. Їхніми послідовниками стали фундатори українських наукових шкіл А. Кримський, М. Галин, О. Потебня, Г. Смаль-Стоцький, І. Ющук та ін.

Після проголошення незалежності України активізувалися процеси, покликані утверджувати українську мову як державну. Особливо активно включилися в цей процес українські поети і письменники - I. Дзюба, Д. Павличко, Л. Костенко, М. Ткач, згодом молоде покоління української творчої еліти - О. Забужко, Ю. Андрухович, М. Жадан та ін. До питання ролі мови у процесі розбудови української держави зверталися провідні мовознавці, історики, філософи. 
Думки всіх учених зводяться до того, що після закріплення статусу української мови як державної в Конституції України іiі престиж, безумовно, підвищився. Проте сподівання на те, що незалежна українська держава в процесі свого становлення виявлятиме максимальну увагу до розвитку й укріплення позицій української мови не справдилися. В Україні не було створено відповідної законодавчої бази щодо мовних питань, а також сприятливих умов для формування престижності і соціальної значущості української мови. Тому нині є підстави твердити про деякі послаблення позицій української мови, досягнутих у перші роки незалежності, що стало проблемою не лише мовною, а й соціальною i навіть державною. Значні прогресивні починання щодо впровадження єдиної концепції мовної політики не переросли в потужну тенденцію, а залишилися декларативними. У загальнодержавному масштабі українська мова не стала державною (офіційною) для всієї України.

Проаналізувавши мовну ситуацію, що склалася у Свропі, приходимо до висновку, що гомогенних країн, тобто таких, де проживає лише одна нація, з притаманною їй мовою, не існує. Відповідно, на територіях майже всіх європейських країн, окрім титульної нації, що дала назву державі, живуть інші автохтонні групи, 3 відмінною мовою і значно меншою чисельністю, ніж чисельність титульної нації. Саме тому європейські держави приділяють серйозну увагу питанням правової регламентації статусу мов, їх використанню в різних галузях життя, а також здійсненню мовної політики. У більшості європейських країн основоположні принципи мовної політики викладені в конституціях. Насамперед визначається статус офіційної мови чи мов. Причому переважна частка країн застосовує конституційно закріплену норму: одна національна держава - одна державна (офіційна) мова, що функціонує на території всієї держави, а питання щодо визначення статусу мов належать до компетенції законодавчих органів держави і регулюються виключно законом.

В Україні є чинним «Закон про мови в УРСР», ухвалений у 1989 році. Його основоположні норми викладені в Конституції України, зокрема iii стаття 10 проголошує державною мовою в Україні українську. Держава забезпечує всебічний розвиток і функціонування української мови в усіх сферах суспільного життя на всій території України. 3 моменту прийняття Закону минуло більше двадцяти років, проте його функціонування досі $\epsilon$ сумнівним, а гасла щодо розвитку й використання української літературної мови декларативними і мало виконуваними. Через це суспільство не налаштоване на серйозне сприйняття законодавчих актів щодо розвитку i функціонування української мови як державної. А мовні питання частогусто зі сфери суто філологічної мігрують у сферу політичну.

Крім того, набирають усе більших масштабів асиміляційні процеси. Українська мова трактується як непридатна для вживання в усіх сферах суспільного життя, а спроби розширити іï функціональний спектр 
розцінюються як витіснення російської. Тому населення України в ситуації, що склалася, не знає жодної літературної мови - ні української, ані російської - а послуговується суржиком, що руйнує засади будь-яких літературних норм і є згубним явищем. У деяких західноєвропейських дослідженнях суржик постає варіантом української літературної мови, адже, як зазначають науковці, ним розмовляє майже весь народ країни, а тих небагатьох, хто говорить правильно, сприймають як диваків і чужаків.

Населення України є двомовним, до того ж, за даними соціологічних досліджень, двомовними є етнічні українці та ті, хто вважає рідною мовою українську. Етнічні росіяни та ті, хто рідною мовою називає російську, є здебільшого одномовними. У зв’язку 3 цим пригадується теза М. Вівчарика, який писав: «Унаслідок взаємодії таких чинників, як багатовікова русифікація, міграція на територію України росіян, фізичне знищення, депортація і вимушена еміграція українців за межі України, створилася вкрай небезпечна і виняткова, суто «російська» ситуація, коли не мігранти змушені докладати зусиль проти їх асиміляції корінним народом, а, навпаки, національно свідомі українці змушені захищатися від мігрантів i доморощених збільшовичених перевертнів» [1, с. 186]. Насторожує й те, що серед російськомовних українців великий відсоток складає молодь, яка використання української мови вважає непрестижним.

Українська мова так і не стала одним із чинників кар'єрного зростання. Нині в Україні можна посісти будь-яку посаду без знання державної мови. Проблема полягає також і в тому, що у країні немає україномовного середовища. Справді, великі міста переважно російськомовні чи двомовні. Українська мова не використовується як розмовна, немає так званого міського сленгу. Телеефір заповнений російськомовною продукцією, переклад українською мовою телесеріалів та більшості кінофільмів здебільшого неякісний, а інколи - примітивний. Товари і послуги рекламують двома мовами - російською та українською. На жаль, і українська книга є малодоступною. По-перше, її видається мало, по-друге, вона значно дорожча за російськомовну. Тираж україномовних газет становить всього 31\%, російськомовних - 64\%, при цьому наклад україномовних газет i періодичних видань щороку зменшується (дані Держкомтелерадіо).

Мовне питання $є$ предметом гострих політичних дискусій. Визначення статусу української мови як єдиної чи не єдиної державної спричиняє соціальну напругу в суспільстві. Неодноразово чуємо тези про те, що справжні патріоти мають розмовляти українською. Але ж, очевидно, патріотизм вимірюється не тільки знанням державної мови, а й прагненням до добробуту українського народу, вивченням його культурних здобутків, розширенням національних інтересів тощо. Розмовляти українською повинно стати не обов'язком, а потребою i політиків, i державних 
службовців, і медиків, й освітян, і науковців, і пересічних громадян. Тільки за таких умов українська мова стане загальнодержавною.

Деякі зрушення за часи незалежності щодо використання української мови відбулися у сфері освіти. У багатьох західних та центральних регіонах України і дошкільна, і середня, і вища освіта майже стовідсотково україномовна. Як зазначає С.Срмоленко, «у свідомості батьків вивчення української мови пов'язане з освітою і культурою... I в цьому можна вбачати запоруку майбутнього зростання соціального престижу української мови як ознаки освіченої, культурної людини» [2]. Значно більше уваги нині приділяється вивченню української мови в середніх школах. Змінився підхід до вивчення української мови, а отже, принципи, мета і завдання. Основний акцент зроблено на виробленні комунікативних умінь і навичок. Діти вчаться мислити по-українськи. Але для значної кількості дітей школа є чи не єдиним місцем, де вони перебувають хоч би частково в україномовному середовищі і мають можливість спілкуватися українською. Часто україномовною школа є тільки впродовж занять, а на перервах та за межами школи і вчителі, й діти спілкуються російською чи мовами інших національних меншин.

Дещо гірше ситуація склалася у вищій школі. Хоч викладання основних предметів ведеться українською мовою, кількість годин, відведених на іiі вивчення, щороку зменшується. Саме тому варто переглянути навчальні плани для вищої школи, оскільки досконале вивчення мови майбутніми фахівцями - це запорука їх вільного самовираження в майбутній професії, науковій та офіційній сферах спілкування. Знання державної мови - це один із компонентів професійної підготовки, той чинник, що підвищує ефективність праці, допомагає краще орієнтуватися у складній професійній ситуації та в контактах із представниками своєї професії.

Отже, стисло проаналізувавши сучасну мовну ситуацію в Україні, можна твердити, що лише пафосних декларацій для утвердження повноцінного функціонування української мови як державної недостатньо. Слід впроваджувати державну мовну політику відповідно до конституційних норм та міжнародно-правових зобов'язань України. Необхідно виробити нові, виважені та послідовні підходи у вирішенні мовних проблем, створивши відповідну законодавчу базу.

1. Вівчарин М. М. Україна : від етносу до нації : [навч. посібник] / М. М. Вівчарин. - К. : Вища школа, 2004. $-219 \mathrm{c}$.

2. Єрмоленко С. Соціальна престижність української мови в сучасному комп'ютерноінформаційному світі. - http://www.ualogos.kiev.ua/: Інститут українознавства. Українознавство. Електронне наукове фахове видання, 2005. Число №4 (17). 